\title{
EXPLORING THE POTENTIAL OF FOUR MEDICINAL PLANTS FOR ANTIOXIDANT ENZYMES ACTIVITY, PROXIMATE AND NUTRITIONAL COMPOSITION
}

\author{
M. F. Akhtar ${ }^{1}$, A. Parveen ${ }^{1}$, A. Hussain ${ }^{1 *}$, M. Z. Mumtaz ${ }^{2}$ \\ M. Kamran ${ }^{3}$, M. A. Faroogi ${ }^{4}$ and M. Ahmad ${ }^{1}$ \\ ${ }^{1}$ Department of Soil Science, University College of Agriculture and Environmental Sciences, \\ The Islamia University of Bahawalpur, Bahawalpur, 63100, Pakistan \\ E-mail:*azharhaseen@gmail.com \\ ${ }^{2}$ Institute of Molecular Biology and Biotechnology, The University of Lahore \\ Defence Road Campus, Lahore, Pakistan \\ ${ }^{3}$ Key Laboratory of Arable Land Conservation, College of Resources and Environment \\ Huazhong Agricultural University, Wuhan 430070, P. R. China \\ ${ }^{4}$ Department of Entomology, University College of Agriculture and Environmental Sciences \\ The Islamia University of Bahawalpur, Bahawalpur, 63100, Pakistan
}

(Received: 10 August, 2018; Accepted: 10 February, 2019)

\begin{abstract}
A study was conducted to evaluate the antioxidant enzymes activity, proximate and nutritional composition of four medicinal plants, which may contribute to folk pharmacological use in the treatment of different diseases. Plant samples were extracted and antioxidant enzymes like superoxide dismutase (SOD), peroxidase (POD), polyphenol oxidase (PPO) and ascorbate peroxide (APX) activity were estimated. Medicinal plants were also analysed for moisture, ash, protein, fibre, carbohydrate, and fats contents. Plant samples were wet digested and mineral composition in terms of nitrogen $(\mathrm{N})$, phosphorus $(\mathrm{P})$, potassium $(\mathrm{K})$, calcium $(\mathrm{Ca})$, magnesium $(\mathrm{Mg})$, and sodium $(\mathrm{Na})$ was determined. The results revealed that antioxidant activity, proximate and nutritional composition differs significantly among tested medicinal plants extract. The leaves of medicinal plants showed more proximate composition (moisture contents, crude protein, fats contents), nutrient accumulation (N, P, K, Ca, Mg and Na), and antioxidant enzymes (POD, PPO, and APX activity). Among medicinal plants, Tribulus terrestris L. showed the highest amount of crude protein, crude fibre, gross energy, and $\mathrm{N}$ and Ca contents. Maximum $\mathrm{K}, \mathrm{Mg}, \mathrm{Na}$ contents, POD, PPO and APX activity was observed in Cenchrus ciliaris L. The ash, fats, phosphorus and SOD activity was more in Euphorbia hirta L. While, Cyperus rotundus L. produced maximum carbohydrates concentration among the tested plants. It is concluded that the target medicinal species had emerged as a good source of the antioxidant and nutritive source, which could play an important role in human nutrition. The extracts of these plants parts can be used in the synthesis of mineral and antioxidant-containing drugs and medicines. This study will provide a baseline for the pharmacology industry.
\end{abstract}

Key words: antioxidants, Cholistan Desert, folk medicine, medicinal plants, minerals 


\section{INTRODUCTION}

The Cholistan Desert of Bahawalpur is a part of the world's seventh largest desert, the Great Desert, which is extended about an area of $26,000 \mathrm{~km}^{2}$ of the southern border of Punjab, Pakistan. The desert climate is xeric, harsh, hot and arid (Arshad et al. 2007, Hameed et al. 2011). Its soil is rated as poor because it contains negligible amounts of organic matter, macro, and micronutrients. Natural flora of the Cholistan Desert consists of many kinds of grass and perennial shrubs, which are adapted to a variety of environmental stresses like extreme aridity, salinity, temperature, nutrients deficiencies and frequently used to cure chronic and acute diseases (Arshad et al. 2007).

Ethnopharmacologically characteristics of the plants of the Cholistan Desert is almost non-existent except very few reports. Many plants of the Cholistan Desert are frequently used by the local inhabitants through using traditional knowledge. Plant-derived products are considered to be major source of modern drugs. Those products possessed biological activity in terms of vermicidal, anthelmintic, antibacterial, and antifungal activities (Immanuel and Elizabeth 2009, Qureshi et al. 2010). Among medicinal flora of the Cholistan Desert, Cyperus rotundus L. is composed of several pharmacologically active substances viz. pinene, cyperol, isocyperol, cyperone, rotundene, rotundenol, rotundone, selinatriene, and sitosterol (Hameed et al. 2011, Immanuel and Elizabeth 2009, Kumar et al. 2010). Its roots are used to cure cough, ingestion, dysentery, diarrhoea, epilepsy, cholera, and flatulence. Its stem had a potential to cure wound, sores, erysipelas and common fever. While, whole plant parts are used to treat blood disorder (Immanuel and Elizabeth 2009). Euphorbia hirta is nutritionally rich and composed of diterpene polyesters and other terpenes (Immanuel and Elizabeth 2009). It is widely used as a medicinal herb as its whole plant parts possessed potential to treat cough, bronchitis, piles, nausea and vomiting, skin inflammation and boils (Immanuel and Elizabeth 2009, Kumar et al. 2010). Tribulus terrestris is used in homeopathic medicines as a libido enhancing supplement (Kumar et al. 2010). Its roots and leaves are used to improve blood circulation, heart and sexual health. Cenchrus ciliaris is the most acceptable and nutritious grass of the Cholistan Desert, and possesses anodyne, diuretic, emollient, anti-inflammatory, antibacterial, and anthelmintic properties (Arshad et al. 2007). Its underground runner is used to relief against body pain, urinary tract infection, and menstrual disorders (Arshad et al. 2007, Immanuel and Elizabeth 2009).

Medicinal plants produce different antioxidative compounds to rectify reactive oxygen species (ROS) in order to stay alive under environmental stress. Recent research focused on discovering an adequate antidote in the form of antioxidants from natural origins to treat different diseases and to check aging signs. The screening of medicinal and foods plants for antioxi- 
dant properties have been observed progressively in the last few decades. Various types of medicinal plants have their individual nutrient constitution beyond having pharmacologically significance. These nutrients are necessary for corporeal operations of the human body. The phytochemicals like fats, proteins, and carbohydrates also play a significant role in satiating human demands for energy and life practice (Adnan et al. 2010).

The Cholistan Desert of Bahawalpur, Pakistan is rich in medicinal plants but due to the lack of knowledge, people of this area are not well aware of beneficial aspects of these medicinal plants. Keeping in view the above facts, the present study was conducted to evaluate the nutritional and proximate composition and antioxidant activity of commonly occurred medicinal plants in the Cholistan Desert, Bahawalpur, Pakistan.

\section{MATERIALS AND METHODS}

Collection of medicinal plants: The plant's root, leaves, and stems samples of Cyperus rotundus, Tribulus terrestris, Cenchrus ciliaris, and Euphorbia hirta. were collected from surrounding desert area of the Islamia University of Bahawalpur, Punjab, Pakistan, located at latitude: $29.38^{\circ} \mathrm{N}$, longitude: $71.76^{\circ}$ $\mathrm{E}$, and $123 \mathrm{~m}$ elevation above the sea level. The specimens were identified according to flora of Pakistan (Hameed et al. 2011) (Table 1). Rhizospheric soil sample representing the growth zone of each selected medicinal plant were analysed and data are presented in Table 2.

Proximate analysis: The roots, leaves, and stems samples were washed with tap and distilled water. These samples were finely ground manually and analysed for moisture and ash contents by following the recommended methods of Association of Official Analytical Chemists (Horwitz 1977). The mois-

\section{Table 1}

Medicinal plants of the Cholistan Desert, Pakistan used in the experiment along with their families, habitat, life span, and life form

\begin{tabular}{llllll}
\hline Scientific name & Family & $\begin{array}{l}\text { Vernacular } \\
\text { name }\end{array}$ & Habit & Life span & Life form \\
\hline Cyperus rotundus & $\begin{array}{l}\text { Cypera- } \\
\text { ceae }\end{array}$ & Nutgrass & sedge & perennial & hemicryptophyte \\
Cenchrus ciliaris & Poaceae & $\begin{array}{l}\text { Buffel grass } \\
\text { (Dhaman) }\end{array}$ & grass & perennial & hemicryptophyte \\
Tribulus terrestris & $\begin{array}{l}\text { Zygophyl- } \\
\text { laceae }\end{array}$ & $\begin{array}{l}\text { Puncture vine, } \\
\text { Devil weed }\end{array}$ & herb & annual & therophyte \\
Euphorbia hirta & $\begin{array}{l}\text { Euphor- } \\
\text { biaceae }\end{array}$ & $\begin{array}{l}\text { Asthma weed, } \\
\text { Dudhi }\end{array}$ & herb & annual & therophyte \\
\hline
\end{tabular}

The data is taken from Hameed et al. (2011) 
Table 2

Physico-chemical characteristics of rhizospheric soil of medicinal plants of the Cholistan

Desert, Pakistan

\begin{tabular}{lcccc}
\hline Characteristics & $\begin{array}{c}\text { Cyperus } \\
\text { rotundus }\end{array}$ & $\begin{array}{c}\text { Cenchrus } \\
\text { ciliaris }\end{array}$ & $\begin{array}{c}\text { Tribulus } \\
\text { terrestris }\end{array}$ & $\begin{array}{c}\text { Euphorbia } \\
\text { hirta }\end{array}$ \\
\hline Textural class & silt loam & silt loam & sandy loam & sandy loam \\
pHs & 8.1 & 8.1 & 8.2 & 8.2 \\
ECe $\left(\mathrm{dS} \mathrm{m}^{-1}\right)$ & 1.42 & 1.34 & 1.30 & 1.21 \\
Total nitrogen $(\%)$ & 0.04 & 0.02 & 0.02 & 0.03 \\
Available P $\left(\mathrm{mg} \mathrm{kg}^{-1}\right)$ & 10.23 & 9.58 & 9.64 & 9.61 \\
Extractable ${\mathrm{K}\left(\mathrm{mg} \mathrm{kg}^{-1}\right)}^{132.2}$ & 125.8 & 126.7 & 117.7 \\
\hline
\end{tabular}

ture content of plant tissues was assessed by taking plant samples and weighing before and after incubation in an oven at $50^{\circ} \mathrm{C}$ and incubated for overnight followed by cooling in a desiccator. For ash content, samples were weighed before and after incineration in a muffle furnace at $600{ }^{\circ} \mathrm{C}$ and cooled in desiccators. Crude protein was estimated by multiplying the $\% \mathrm{~N}$ with a factor of 6.25 (Khanzada et al. 2008). For estimation of crude fibre content, $2 \mathrm{~g}$ of sample along with $1.25 \% \mathrm{H}_{2} \mathrm{SO}_{4}(200 \mathrm{~mL})$ was boiled for $30 \mathrm{~min}$. The $\mathrm{NaOH}(200 \mathrm{~mL})$ was added in filtrate residues and boiled for $30 \mathrm{~min}$ to dissolve alkali and acid soluble components and filtered. The residue was oven dried at $105^{\circ} \mathrm{C}$ and placed in a muffle furnace at $500{ }^{\circ} \mathrm{C}$ for $3 \mathrm{~h}$. Crude fibre content was calculated through using equation described by Ashraf et al. (2013). For determination of fat contents, dried plant sample was extracted with petroleum ether by using a Soxhlet apparatus to eliminate the ether-soluble component and dried at 70 ${ }^{\circ} \mathrm{C}$ in an oven to a constant weight (Ashraf et al. 2013). Total carbohydrates were determined by subtracting the values of crude protein, crude fibre, fat, moisture and ash content from a factor of 100 (Dastagir et al. 2013). Gross energy was calculated by using the formula described by Garrett and Johnson (1983).

Determination of antioxidant activity: For determination of antioxidant activity, plant root and leaves samples $(0.5 \mathrm{~g})$ were taken in pre-cooled mortar on the ice and $5 \mathrm{ml}$ of pre-cooled phosphate buffer solution was added. The samples were homogenised on ice and centrifuged at 10,000 rpm for 20 min at $4{ }^{\circ} \mathrm{C}$. The supernatant was used to determine superoxide dismutase (SOD) activity by following method of Zhang et al. (2008). According to this method, $0.1 \mathrm{~mL}$ of extract supernatant was mixed with $0.25 \mathrm{~mL} \mathrm{H}_{2} \mathrm{O}_{2}$ and 2.73 $\mathrm{mL}$ reaction solution (prepared from nitro blue tetrazolium (NBT) chloride, riboflavin, methionine, and ethylene diamine tetra acetic acid). The solution was incubated in a light box for fifteen minutes and absorbance was taken 
on spectrophotometer (Model G6860A, Agilent Technologies Cary 60 UV-Vis, Australia) at $560 \mathrm{~nm}$.

The method of Zhou and Leul (1999) was employed for the determination peroxidase (POD) activity of plant extract. The $0.1 \mathrm{~mL}$ of enzymes extract along with $0.1 \mathrm{~mL}$ guaiacol $(1.5 \%), 0.1 \mathrm{~mL} \mathrm{H}_{2} \mathrm{O}_{2}(300 \mathrm{mM})$ and $2.7 \mathrm{~mL}$ phosphate buffer $(50 \mathrm{mM})$ were taken in test tubes. Samples absorbance was noted on spectrophotometer at $470 \mathrm{~nm}$. The method of Mayer et al. (1966) was used to determine polyphenol oxidase (PPO) activity by mixing supernatant extract $(0.1 \mathrm{~mL})$ with chlorogenic acid up to $3 \mathrm{~mL}$ final volume and absorbance was taken at $265 \mathrm{~nm}$. While, ascorbate peroxidase (APX) activity was determined according to Nakano and Asada (1981). For APX activity, $0.1 \mathrm{~mL}$ enzyme extracts with $0.1 \mathrm{~mL}$ of ascorbate acid $(7.5 \mathrm{mM}), 0.1 \mathrm{~mL}$ of $\mathrm{H}_{2} \mathrm{O}_{2}(300$ $\mathrm{mM}$ ) and $2.7 \mathrm{~mL}$ of phosphate buffers were mixed and absorbance was determined by spectrophotometer at $290 \mathrm{~nm}$.

Mineral quantification: For evaluation of nutritional composition, plant samples were wet digested (Wolf 1982). The volume of the digested plant extract was made to $50 \mathrm{~mL}$ in volumetric flasks and preserved for further mineral analysis. Mineral composition of roots, leaves and stems were determined as follows: $\mathrm{N}$ through micro-Kjeldahl method; $\mathrm{P}$ by treating the digested samples with Barton reagents as described by Jackson (1962); K, Na, and Ca were determined by Flame Photometer (BWB technologies, UK, Ltd.) and $\mathrm{Mg}$ was measured with atomic absorption spectrophotometer (Agilent Technologies, Australia).

Statistical analysis: The data was analysed using statistical package Statistix 8.1 by applying the completely randomised design. Least significant difference test (LSD) was applied to calculate the non-significant difference at $5 \%$ probability (Steel and Torrie 1986).

\section{RESULTS}

The medicinal plants, viz. Cyperus rotundus, Tribulus terrestris, Cenchrus ciliaris, and Euphorbia hirta were selected on basis of their local medicinal use as herbal remedies for the treatments of diseases. C. rotundus and T. terrestris belong to perennial life span and hemicryptophyte life form collected from silt loam soil whereas, $C$. ciliaris and E. hirta belong to annual life span and therophyte life form collected from sandy loam soil (Tables 1 and 2).

\section{Proximate composition}

The proximate analysis of various parts of medicinal plants as represented by Table 3 showed that the leaves had the highest moisture contents, crude 
Table 3

Proximate composition of medicinal plants of the Cholistan Desert, Pakistan

\begin{tabular}{|c|c|c|c|c|c|c|}
\hline Proximate composition & $\begin{array}{l}\text { Plant } \\
\text { tissue }\end{array}$ & $\begin{array}{l}\text { Cyperus } \\
\text { rotundus }\end{array}$ & $\begin{array}{l}\text { Cenchrus } \\
\text { ciliaris }\end{array}$ & $\begin{array}{l}\text { Tribulus } \\
\text { terrestris }\end{array}$ & $\begin{array}{l}\text { Euphorbia } \\
\text { hirta }\end{array}$ & $\begin{array}{l}\text { LSD } \\
\text { value }\end{array}$ \\
\hline \multirow[t]{3}{*}{ Moisture contents (\%) } & Roots & $9.15^{\mathrm{b}}$ & $41.2^{\mathrm{a}}$ & $8.19^{\mathrm{b}}$ & $7.17^{c}$ & 0.9720 \\
\hline & Stems & $13.04^{\mathrm{b}}$ & $49.17^{a}$ & $8.67^{c}$ & $7.81^{\mathrm{d}}$ & 0.7122 \\
\hline & Leaves & $10.83^{b}$ & $58.31^{\mathrm{a}}$ & $9.34^{c}$ & $10.16^{\mathrm{bc}}$ & 0.8265 \\
\hline \multirow[t]{3}{*}{ Ash contents (\%) } & Roots & $10.30^{\mathrm{b}}$ & $9.42^{c}$ & $5.87^{\mathrm{d}}$ & $17.26^{\mathrm{a}}$ & 0.8727 \\
\hline & Stems & $8.91^{\mathrm{d}}$ & $10.20^{c}$ & $12.05^{\mathrm{b}}$ & $13.56^{\mathrm{a}}$ & 0.9433 \\
\hline & Leaves & $11.43^{\text {bc }}$ & $11.67^{\mathrm{b}}$ & $10.67^{c}$ & $15.56^{\mathrm{a}}$ & 0.7914 \\
\hline \multirow[t]{3}{*}{ Carbohydrate contents (\%) } & Roots & $38.68^{a}$ & $15.79^{c}$ & $22.54^{\mathrm{b}}$ & $13.54^{\mathrm{d}}$ & 0.5733 \\
\hline & Stems & $30.29^{\mathrm{a}}$ & $14.81^{\mathrm{c}}$ & $12.00^{\mathrm{d}}$ & $16.53^{b}$ & 0.7828 \\
\hline & Leaves & $41.47^{\mathrm{a}}$ & $12.41^{\mathrm{d}}$ & $19.33^{c}$ & $35.33^{\mathrm{b}}$ & 0.3491 \\
\hline \multirow[t]{3}{*}{ Crude protein (\%) } & Roots & $4.08^{c}$ & $6.60^{\mathrm{b}}$ & $8.52^{\mathrm{a}}$ & $7.29^{\mathrm{b}}$ & 0.7501 \\
\hline & Stems & $7.89^{\mathrm{b}}$ & $3.08^{c}$ & $10.59^{a}$ & $2.73^{c}$ & 0.5962 \\
\hline & Leaves & $9.67^{c}$ & $15.12^{\mathrm{b}}$ & $16.44^{\mathrm{a}}$ & $8.16^{\mathrm{d}}$ & 0.7236 \\
\hline \multirow[t]{3}{*}{ Fats contents (\%) } & Roots & $7.04^{\mathrm{b}}$ & $3.60^{d}$ & $5.04^{c}$ & $8.16^{\mathrm{a}}$ & 0.7258 \\
\hline & Stems & $8.65^{\mathrm{b}}$ & $5.55^{\mathrm{d}}$ & $8.33^{c}$ & $11.22^{\mathrm{a}}$ & 0.6850 \\
\hline & Leaves & $8.94^{\mathrm{b}}$ & $5.79^{c}$ & $8.17^{\mathrm{b}}$ & $16.22^{\mathrm{a}}$ & 0.6081 \\
\hline \multirow[t]{3}{*}{ Crude fiber (\%) } & Roots & $25.84^{\mathrm{d}}$ & $48.32^{c}$ & $56.57^{a}$ & $54.75^{\mathrm{b}}$ & 1.1610 \\
\hline & Stems & $31.83^{\mathrm{d}}$ & $39.89^{c}$ & $60.07^{a}$ & $48.15^{\mathrm{b}}$ & 1.2653 \\
\hline & Leaves & $17.65^{c}$ & $35.23^{b}$ & $44.07^{\mathrm{a}}$ & $8.82^{\mathrm{d}}$ & 1.3171 \\
\hline \multirow[t]{3}{*}{ Gross energy $\left(\mathrm{Kcal} \mathrm{g}^{-1}\right)$} & Roots & $393.4^{c}$ & $371.3^{\mathrm{d}}$ & $421.3^{\mathrm{a}}$ & $404.5^{\mathrm{b}}$ & 5.2315 \\
\hline & Stems & $398.9^{c}$ & $384.5^{\mathrm{d}}$ & $439.5^{\mathrm{a}}$ & $419.5^{\mathrm{b}}$ & 7.8451 \\
\hline & Leaves & $391.9^{c}$ & $360.1^{\mathrm{d}}$ & $450.7^{\mathrm{a}}$ & $420.3^{b}$ & 11.257 \\
\hline
\end{tabular}

LSD = least significant difference; data are mean values of three replicates $(p \leq 0.05)$; Means sharing the same letter (s) do not differ significantly according to least significant test.

protein, and fats contents ranged from 9.3 to $58.3 \%, 8.2$ to $16.4 \%$ and 5.8 to $16.2 \%$, respectively. The stem of tested medicinal plants showed more crude fibre contents and gross energy as compared to leaves and roots that ranged from 31.8 to $60.0 \%$ and 398.9 to $439.5 \mathrm{Kcal} \mathrm{g}^{-1}$, respectively. More carbohydrate contents were recorded in plant roots, which ranged from 9.42 to $17.3 \%$ and 13.54 to $38.7 \%$, respectively. Among medicinal plants, T. terrestris showed the highest amount of crude protein contents, crude fibre contents, and gross energy in roots, stem, and leaves. Maximum ash and fats contents were observed in roots, stem, and leaves of E. hirta. While, maximum carbohydrate contents in roots, stem, and leaves were recorded of $C$. rotundus. 


\section{Nutritional composition}

The minerals composition in terms of primary and secondary macronutrients in leaves, stem and roots of medicinal plants were recorded (Table 4). The results revealed that leaves of medicinal plants were more enriched with minerals as compared to stem and roots. The $\mathrm{N}$ contents of medicinal plants ranged from 0.65 to $1.36 \%$ in roots, 0.44 to $1.69 \%$ in stem and 1.31 to $2.63 \%$ in leaves. Maximum N content of roots, stems, and leaves was observed from T. terrestris compared to other tested medicinal plants. The detected $\mathrm{P}$ contents in medicinal plants ranged from 0.41 to $0.57 \%$ in roots, 0.43 to $0.55 \%$ in stem and 0.46 to $0.83 \%$ in leaves. Maximum P contents were accumulated in roots and leaves of $E$. hirta. Phosphorus contents in stem of $C$. ciliaris were

Table 4

Macro minerals of medicinal plants of the Cholistan Desert, Pakistan

\begin{tabular}{|c|c|c|c|c|c|c|}
\hline $\begin{array}{l}\text { Minerals } \\
\text { composition* }\end{array}$ & $\begin{array}{l}\text { Plant } \\
\text { tissue }\end{array}$ & $\begin{array}{l}\text { Cyperus } \\
\text { rotundus }\end{array}$ & $\begin{array}{l}\text { Cenchrus } \\
\text { ciliaris }\end{array}$ & $\begin{array}{l}\text { Tribulus } \\
\text { terrestris }\end{array}$ & $\begin{array}{l}\text { Euphorbia } \\
\text { hirta }\end{array}$ & $\begin{array}{l}\text { LSD } \\
\text { value }\end{array}$ \\
\hline \multirow[t]{3}{*}{$\mathrm{N}$ content $(\%)$} & Roots & $0.65^{c}$ & $1.06^{\mathrm{b}}$ & $1.36^{\mathrm{a}}$ & $1.17^{\mathrm{b}}$ & 0.1203 \\
\hline & Stems & $1.26^{\mathrm{b}}$ & $0.49^{c}$ & $1.69^{\mathrm{a}}$ & $0.44^{c}$ & 0.0958 \\
\hline & Leaves & $1.55^{\mathrm{c}}$ & $2.42^{\mathrm{b}}$ & $2.63^{\mathrm{a}}$ & $1.31^{\mathrm{d}}$ & 0.1163 \\
\hline \multirow[t]{3}{*}{ P contents $(\%)$} & Roots & $0.41^{\mathrm{c}}$ & $0.41^{\mathrm{c}}$ & $0.50^{\mathrm{b}}$ & $0.57^{a}$ & 0.0511 \\
\hline & Stems & $0.45^{\mathrm{b}}$ & $0.55^{\mathrm{a}}$ & $0.43^{\mathrm{b}}$ & $0.51^{\mathrm{a}}$ & 0.0548 \\
\hline & Leaves & $0.47^{c}$ & $0.54^{\mathrm{b}}$ & $0.46^{c}$ & $0.83^{\mathrm{a}}$ & 0.0436 \\
\hline \multirow[t]{3}{*}{ K contents (\%) } & Roots & $0.32^{c}$ & $1.08^{\mathrm{a}}$ & $0.46^{\mathrm{b}}$ & $0.44^{\mathrm{b}}$ & 0.0950 \\
\hline & Stems & $0.77^{\mathrm{c}}$ & $1.36^{\mathrm{a}}$ & $0.73^{c}$ & $1.13^{\mathrm{b}}$ & 0.1189 \\
\hline & Leaves & $0.83^{c}$ & $1.48^{\mathrm{a}}$ & $1.16^{\mathrm{b}}$ & $0.63^{\mathrm{d}}$ & 0.0969 \\
\hline \multirow[t]{3}{*}{ Na contents (\%) } & Roots & $0.18^{\mathrm{b}}$ & $0.22^{\mathrm{a}}$ & $0.08^{\mathrm{d}}$ & $0.12^{c}$ & 0.0354 \\
\hline & Stems & $0.16^{\mathrm{a}}$ & $0.19^{a}$ & $0.05^{\mathrm{b}}$ & $0.09^{\mathrm{b}}$ & 0.0483 \\
\hline & Leaves & $0.21^{\mathrm{b}}$ & $0.58^{\mathrm{a}}$ & $0.06^{c}$ & $0.07^{c}$ & 0.0429 \\
\hline \multirow[t]{3}{*}{ Ca contents $(\%)$} & Roots & $0.38^{\mathrm{b}}$ & $0.42^{\mathrm{b}}$ & $0.63^{a}$ & $0.42^{b}$ & 0.0852 \\
\hline & Stems & $0.51^{\mathrm{bc}}$ & $0.41^{\mathrm{c}}$ & $1.16^{\mathrm{a}}$ & $0.53^{\mathrm{b}}$ & 0.1014 \\
\hline & Leaves & $0.45^{c}$ & $0.53^{\mathrm{bc}}$ & $1.80^{\mathrm{a}}$ & $0.59^{\mathrm{b}}$ & 0.0902 \\
\hline \multirow[t]{3}{*}{ Mg contents $\left(\mu g^{-1}\right)$} & Roots & $1552.7^{b}$ & $1803.0^{\mathrm{a}}$ & $1148.7^{\mathrm{d}}$ & $1252.7^{c}$ & 48.380 \\
\hline & Stems & $1352.3^{b}$ & $1508.7^{\mathrm{a}}$ & $1245.3^{c}$ & $1028.7^{\mathrm{d}}$ & 54.443 \\
\hline & Leaves & $2129.0^{\mathrm{b}}$ & $2275.7^{\mathrm{a}}$ & $1600.7^{c}$ & $1126.3^{\mathrm{d}}$ & 45.724 \\
\hline
\end{tabular}

*mineral composition in roots, stem and leaves of target medicinal plant was evaluated; $\mathrm{N}$ = nitrogen; $\mathrm{P}=$ phosphorus; $\mathrm{K}$ = potassium; $\mathrm{Ca}=$ calcium; $\mathrm{Mg}=$ magnesium; $\mathrm{Na}=$ sodium; data are mean values of three replicates $(p \leq 0.05)$; Means sharing the same letter (s) do not differ significantly according to least significant test; LSD = least significant difference 
Table 5

Antioxidant enzymes activity of medicinal plants of the Cholistan Desert, Pakistan

\begin{tabular}{|c|c|c|c|c|c|c|}
\hline $\begin{array}{l}\text { Antioxidant } \\
\text { enzymes activity }\end{array}$ & $\begin{array}{l}\text { Plant } \\
\text { tissue }\end{array}$ & $\begin{array}{l}\text { Cyperus } \\
\text { rotundus }\end{array}$ & $\begin{array}{l}\text { Cenchrus } \\
\text { ciliaris }\end{array}$ & $\begin{array}{l}\text { Tribulus } \\
\text { terrestris }\end{array}$ & $\begin{array}{l}\text { Euphorbia } \\
\text { hirta }\end{array}$ & $\begin{array}{l}\text { LSD } \\
\text { value }\end{array}$ \\
\hline \multirow[t]{2}{*}{ SOD (units $\mathrm{g}^{-1} \mathrm{FW}$ ) } & Roots & $100.2^{\mathrm{b}}$ & $78.8^{c}$ & $63.9^{\mathrm{d}}$ & $139.5^{\mathrm{a}}$ & 5.7137 \\
\hline & Leaves & $106.6^{\mathrm{b}}$ & $27.9^{\mathrm{d}}$ & $36.7^{c}$ & $136.7^{\mathrm{a}}$ & 5.7900 \\
\hline \multirow{2}{*}{$\begin{array}{l}\text { POD }\left(\mu \mathrm{mol} \mathrm{min}{ }^{-1}\right. \\
\left.\mathrm{mg}^{-1} \text { protein }\right)\end{array}$} & Roots & $3.94^{\mathrm{b}}$ & $8.59^{a}$ & $4.16^{\mathrm{b}}$ & $2.84^{c}$ & 0.8222 \\
\hline & Leaves & $3.12^{\mathrm{c}}$ & $15.31^{\mathrm{a}}$ & $11.66^{\mathrm{b}}$ & $3.74^{\mathrm{c}}$ & 0.8553 \\
\hline \multirow{2}{*}{$\begin{array}{l}\text { PPO (units } \mathrm{mg}^{-1} \\
\text { protein) }\end{array}$} & Roots & $0.216^{\mathrm{b}}$ & $0.323^{\mathrm{a}}$ & $0.113^{c}$ & $0.256^{\mathrm{ab}}$ & 0.0686 \\
\hline & Leaves & $0.287^{\mathrm{b}}$ & $2.220^{\mathrm{a}}$ & $0.322^{\mathrm{b}}$ & $0.044^{c}$ & 0.0883 \\
\hline \multirow[t]{2}{*}{ APX (units g ${ }^{-1} \mathrm{FW}$ ) } & Roots & $196.9^{a}$ & $200.8^{a}$ & $175.9^{\mathrm{b}}$ & $197.3^{\mathrm{a}}$ & 5.8493 \\
\hline & Leaves & $195.6^{\mathrm{d}}$ & $238.6^{\mathrm{a}}$ & $231.3^{\mathrm{b}}$ & $209.9^{c}$ & 4.7793 \\
\hline
\end{tabular}

$\mathrm{SOD}$ = superoxide dismutase; $\mathrm{POD}=$ peroxidases; $\mathrm{PPO}=$ polyphenol oxidase; $\mathrm{APX}=$ ascorbate peroxidase; LSD = least significant difference; data are mean values of three replicates $(p \leq 0.05)$; Means sharing the same letter (s) do not differ significantly according to least significant test

also maximum and statistically similar to E. hirta. The C. ciliaris also reported maximum accumulation of $\mathrm{K}$ in roots, stem, and leaves. The $\mathrm{K}$ contents in roots, stem and leaves of medicinal plants ranged from 0.32 to $1.08 \%, 0.73$ to $1.36 \%$ and 0.63 to $1.48 \%$, respectively.

Among secondary macronutrients, $\mathrm{Ca}$ and $\mathrm{Mg}$ contents were significant among various parts of medicinal plants. The calcium and magnesium contents ranged from 0.38 to $0.63 \%$ and $1,148.7$ to $1,803.0 \mathrm{\mu g} \mathrm{g}^{-1}$, respectively in roots, 0.41 to $1.16 \%$ and $1,028.7$ to $1,508.7 \mu \mathrm{g} \mathrm{g}^{-1}$, respectively in the stem and 0.45 to $1.80 \%$ and $1,126.3$ to $2,275.7 \mu^{-1} \mathrm{~g} \mathrm{~g}^{-1}$, respectively in leaves of tested medicinal plants. Maximum Ca contents were observed in roots, stem, and leaves of T. terrestris, whereas the C. ciliaris reported maximum $\mathrm{Mg}$ contents in roots, stem, and leaves. The Na contents were also detected in various parts of plants and found maximum in roots, stem, and leaves of $C$. ciliaris. The $\mathrm{Na}$ contents in the stem of $C$. ciliaris was statistically non-significant as compared to $\mathrm{Na}$ contents in the stem of $\mathrm{C}$. rotundus.

\section{Antioxidant enzymes activity}

The antioxidant enzyme's activity in leaves and roots of four medicinal plants presented in Table 5 revealed significant variation among the medicinal plants. The SOD activity ranged from 63.9 to 139.5 unit $\mathrm{g}^{-1} \mathrm{FW}$ in leaves and 27.9 to 136.7 unit $\mathrm{g}^{-1} \mathrm{FW}$ in roots of tested medicinal plants. Maximum SOD activity was observed in roots and leaves of E. hirta. The POD activity 
was more in leaves of medicinal plants and ranged from 3.12 to $15.31 \mu \mathrm{mol}$ $\mathrm{min}^{-1} \mathrm{mg}^{-1}$ protein, whereas in plants roots, it ranged from 2.84 to $8.59 \mu \mathrm{mol}$ $\mathrm{min}^{-1} \mathrm{mg}^{-1}$ protein. C. ciliaris showed maximum POD activity in leaves and roots as compared other plants. The PPO and APX activity was more in leaves of medicinal plants, which ranged from 0.05 to 2.22 unit $\mathrm{mg}^{-1}$ protein and 195.6 to 238.6 unit $\mathrm{g}^{-1} \mathrm{FW}$, respectively. The APX activity in roots was nonsignificant among the tested plants. Maximum PPO and APX activity were observed in roots and leaves of $C$. ciliaris. The PPO activity in roots of $C$. ciliaris was statistically similar to the E. hirta.

\section{DISCUSSION}

In the present study, medicinal plants, viz. Cyperus rotundus, Tribulus terrestris, Cenchrus ciliaris, and Euphorbia hirta were selected to study their nutritional composition and antioxidant enzymes activity. Selection of these plant species was made on basis of their local fame in medicinal use as herbal remedies. The habitant of the Cholistan Desert uses different parts of these medicinal plant to cure a digestive tract problem, respiratory diseases, mental illness, skin disorder, hormonal imbalance, and blood disorders (Immanuel and Elizabeth 2009, Kumar et al. 2010).

The current study revealed that tested medicinal plants are enriched with proximate contents and these contents were variable among the tested medicinal plants. This variation could be due to several soil and moisture factors, and genetic potential of target species. In spite of these factors, proximate analysis shows that target plants are good source of minerals, proteins, lipids, carbohydrates and gross energy. The concentration range of proximate attributes was similar to the concentration found in the findings of Hannah and Krishnakumari (2015). High ash contents point out that tested medicinal species are a good source of inorganic minerals. Gross energy values are based on the fats, protein and carbohydrates contents. The highest gross energy was present in T. terrestris thus it is important to the source of food, medicine, fibres and other items, which can be used in industries.

Nutrients play an essential role in the medicinal value of plants to cure disease and improve human health. The analysis of minerals in present study revealed that leaves of target plants were more enriched with minerals as compared to stem and roots. The tested plants showed variations regarding mineral composition as highest $\mathrm{K}, \mathrm{Na}$, and $\mathrm{Mg}$ contents were observed in $\mathrm{C}$. ciliaris. The T. terrestris reported maximum $\mathrm{N}$ and Ca contents, whereas maximum P was accumulated by E. hirta. Similar to our study, Ashraf et al. (2012) reported a similar range of macronutrient concentration in Haloxylon salicornicum L. collected from the Cholistan Desert. Minerals compositions of tested 
plants were comparable to highly valued medicinal Berberis species fruits in Himalayan, India (Andola et al. 2011). The nutrients like N, P, Ca, and Mg accumulated in plants are required to repairs wound, for strong bones and teeth, the building of red blood cells and for body mechanisms (Hannah and Krishnakumari 2015). Potassium is an activator of many enzymes and maintains cardiovascular function, heartbeat and blood pressure (Vaskonen 2003). Sodium contents were also detected in target plants, which is necessary to retain the equilibrium of the physical fluids system and proper functioning of nerve and muscle (Idris et al. 2010).

Dietary consumption of high antioxidant-based plant product is helpful in prevention of complex diseases like cancer and cardiovascular diseases (Carocho and Ferreira 2013, Kris-Etherton et al. 2002). Medicinal plants are rich in wide range of secondary metabolites, viz. phenolic compounds such as flavonoids, tannins, lignans, phenolic acids, which have multiple biological activity including antioxidative activity. In the present study, antioxidant potency of tested medicinal plants was investigated to support its traditional uses as an antioxidant source. Results revealed that tested plants, viz. C. rotundus, C. ciliaris, T. terrestris, and E. hirta demonstrated activity of SOD, POD, PPO, and APX. Antioxidant activity of these plants may be due to their compounds, such as terpenoids, saponins, alkaloids, and phenolic contents, which are powerful antioxidant compounds and positively correlated with antioxidant activity (Khasawneh et al. 2011). Previously, total phenolics and flavonoids in C. rotundus was reported by Yazdanparast and Ardestani (2007). C. rotundus also possess anti-neoplastic properties helpful in cancer therapy (Mannarreddy et al. 2017). Rayed et al. (2010) reported rich amount of phenols and flavonoids in leaves stems, flowers, and roots of E. hirta. This plant possesses antioxidant activity and act as scavenger of free radical (Soare et al. 1997). Traditional use of E. hirta plant extracts non-cytotoxic according to IC50 value adapted from National Cancer Institute (NCI) as reported by Perumal et al. (2013). T. terrestris showed anti-inflammatory, anti-tumor, and anticarcinogenic effect and was used for treatment of kidney and urinary cancers (Kumar et al. 2006). Oral admiration of alcohol extracts C. ciliaris up to 5000 $\mathrm{mg} / \mathrm{kg}$ (LD50) did not produce any sign of toxicity and was considered safe for human use (Awaad et al. 2016).

The overexpression of antioxidant enzymes could be complicated in amelioration of environmental stresses as the Cholistan Desert is characterised as xeric, harsh, and hot and may produce tolerance in plants. Medicinal plants are easily available and a potential source of antioxidant whose phytochemicals and antioxidant may act individually or synergistically to cure disease through their pharmacological properties. 


\section{CONCLUSION}

The present study revealed the fact that the medicinal plants of the Cholistan Desert, Pakistan (Tribulus terrestris, Cenchrus ciliaris, and Euphorbia hirta) are a rich source of antioxidant activity, proximate and minerals nutrition that would serve as potent free radical scavengers and make these species as a promising source of antioxidants and nutrition. The extracts of these plants parts can be used in the synthesis of nutritious and antioxidant-containing folk medicine. Furthermore, such popular plant species could be essential for analysing the bio-active constituent, pharmacology and biological activities which may lead to new and potential drugs for humanity in future.

Acknowledgements - The financial support for research was provided by Department of Soil Science, University College of Agriculture \& Environmental Sciences. The Islamia University Bahawalpur-Pakistan.

\section{REFERENCES}

Adnan, M., Hussain, J., Shah, M. T., Shinwari, Z. K., Ullah, F., Bahader, A., Khan, N., Khan, A. L. and Watanabe, T. (2010): Proximate and nutrient composition of medicinal plants of humid and sub-humid regions in North-west Pakistan. - J. Med. Plants Res. 4: 339-345.

Andola, H. C., Rawal, R. S. and Bhatt, I. D. (2011): Comparative studies on the nutritive and anti-nutritive properties of fruits in selected Berberis species of West Himalaya, India. - Food Res. Int. 44(7): 2352-2356. https://doi.org/10.1016/j.foodres.2010.07.017

Arshad, M., Ashraf, M. Y., Ahmad, M. and Zaman, F. (2007): Morpho-genetic variability potential of Cenchrus ciliaris L. from Cholistan desert, Pakistan. - Pak. J. Bot. 39(5): 1481-1488.

Ashraf, M. A., Karamat, M., Shahnaz, K., Abdul, W. and Ismail, Y. (2012): Study of chemical and mineral constituents of Haloxylon salicornicum collected from Cholistan Desert, Bahawalpur, Pakistan. - Wulfenia J. 19(10): 306-327.

Ashraf, M. A., Mahmood, K., Yusoff, I. and Qureshi, A. K. (2013): Chemical constituents of Cenchrus ciliaris L. from the Cholistan desert, Pakistan. - Arch. Biol. Sci. 65(4): 1473-1478. https://doi.org/10.2298/abs1304473a

Awaad, A. S., Al-Refaie, A., El-Meligy, R. M., Zain, M. E., Soliman, H., Marzoke, Mohamed, S. and El-Sayed, N. H. (2016): Novel compounds with new anti-ulcerogenic activity from Convolvulus pilosellifolius using bio-guided fractionation. - Phytother. Res. 30: 2060-2064. https://doi.org/10.1002/ptr.5730

Carocho, M. and Ferreira, I. C. F. R. (2013): The role of phenolic compounds in the fight against cancer: a review. - Anti-Cancer Agents Medic. Chem. 13: 1236-1258. https://doi. org/10.2174/18715206113139990301 
Dastagir, G., Hussain, F., Khattak, F. and Khandazi (2013): Proximate analysis of plants of family Zygophyllaceae and Euphorbiaceae during winter. - Sarhad J. Agric. 29(3): 395-400.

Garrett, W. N. and Johnson, D. E. (1983): Nutritional energetics of ruminants. - J. Anim. Sci. 57(2): 478-497.

Hameed, M., Ashraf, M., Al-Quriany, F., Nawaz, T., Ahmad, M. S. A., Younis, A. and Naz, N. (2011): Medicinal flora of the Cholistan desert: a review. - Pak. J. Bot. 43: 39-50.

Hannah, M. A. C. and Krishnakumari, S. (2015): Analysis of mineral elements, proximate and nutritive value in Citrullus vulgaris Schrad. (watermelon) seed extracts. - Pharm. Innov. J. 4(8a): 7.

Horwitz, W. (1977): The variability of AOAC methods of analysis as used in analytical pharmaceutical chemistry. - J. Assoc. Off. Anal. Chem. 60(6): 1355-1363.

Idris, S., Ndamitso, M. M., Yisa, J., Dauda, B. E. N. and Jacob, J. O. (2010): The proximate and mineral composition of the leaves and stems of Balanites aegyptiaca. - Int. J. Appl. Biol. Res. 2: 76-87.

Immanuel, R. R. and Elizabeth, L. L. (2009): Weeds in agroecosystems: a source of medicines for human healthcare. - Int. J. Pharm. Tech. Res. 1: 375-385.

Jackson, M. L. (1962): Soil chemical analysis. - Prentice Hall. Inc., Englewood Cliffs, New York.

Khanzada, S. K., Shaikh, W., Kazi, T. G., Sofia, S., Kabir, A., Usmanghani, K. and Kandhro, A. A. (2008): Analysis of fatty acid, elemental and total protein of Calotropis procera medicinal plant from Sindh, Pakistan. - Pak. J. Bot. 40(5): 1913-1921.

Khasawneh, M. A., Elwy, H. M., Fawzi, N. M., Hamza, A. A., Chevidenkandy, A. R. and Hassan, A. H. (2011): Antioxidant activity, lipoxygenase inhibitory effect and polyphenolic compounds from Calotropis procera (Ait.) R. Br. - Res. J. Phytochem. 5: 8088. https://doi.org/10.3923/rjphyto.2011.80.88

Kris-Etherton, P. M., Hecker, K. D., Bonanome A., Coval, S. M., Binkoski, A. E., Hilpert, K. F., Griel, A. E. and Etherton, T. D. (2002): Bioactive compounds in foods: their role in the prevention of cardiovascular disease and cancer. - Amer. J. Medicine 113: 71-88. https://doi.org/10.1016/s0002-9343(01)00995-0

Kumar, M., Soni, A. K., Shukla, S. and Kumar, A. (2006): Chemopreventive potential of Tribulus terrestris against dimethylbenz (a) anthracene induced skin papillomagenesis in mice. - Asian Pac. J. Cancer Prev. 7: 289-294.

Kumar, R. P., Kumar, R., Malhotra, Y., Sharma, D. and Karthiyagini, T. (2010): Standardization and preliminary phytochemical investigation on Cyperus rotundus Linn. rhizome. - Int. J. Res. Ayurveda Pharm. 1(2): 536-542.

Mannarreddy, P., Denis, M., Munireddy, D., Pandurangan, R., Thangavelu, K. P. and Venkatesan, K. (2017): Cytotoxic effect of Cyperus rotundus rhizome extract on human cancer cell lines. - Biomed. Pharmacother. 95: 1375-1387. https://doi.org/10.1016/j.biopha.2017.09.051

Mayer, A. M., Harel, E. and Ben-Shaul, R. (1966): Assay of catechol oxidase - a critical comparison of methods. - Phytochem. 5(4): 783-789. https://doi.org/10.1016/s00319422(00)83660-2

Menon, D., Dharmapal, S., Achuthan, C. R. and Babu, T. D. (2014): Cytotoxic and antitumor effects of Tribulus terrestris L fruit methanolic extract. - J. Pharmacognosy Phytochem. 3: 1-4. 
Nakano, Y. and Asada, K. (1981): Hydrogen peroxide is scavenged by ascorbate-specific peroxidase in spinach chloroplasts. - Plant Cell Physiol. 22(5): 867-880. https://doi. org/10.1093/oxfordjournals.pcp.a076232

Parida, A. K. and Das, A. B. (2005): Salt tolerance and salinity effects on plants: a review. - Ecotoxicol. Environm. Safety 60(3): 324-349. https://doi.org/10.1016/j.ecoenv.2004.06.010

Perumal, S., Mahmud, R., Piaru, S. P., Lee, W. C. and Ramanathan, S. (2013): Antiradical and cytotoxic activities of varying solvent polarity extracts of the aerial part of Euphorbia hirta L. - J. Chem. 2013: Article ID 983253, 6 pp. https://doi.org/10.1155/2013/983253

Qureshi, R., Bhatti, G. R. and Memon, R. A. (2010): Ethnomedicinal uses of herbs from northern part of Nara desert, Pakistan. - Pak. J. Bot. 42: 839-851.

Rayeh, M., A. B. R., Zuraini, Z., Sasidharan, S., Latha, L. Y. and Amutha, S. (2010): Assessment of Euphorbia hirta L. leaf, flower, stem and root extracts for their antibacterial and antifungal activity and brine shrimp lethality. - Molecules 15: 6008-6018. https:// doi.org/10.3390/molecules15096008

Soare, J. R., Dinis, T. C. P., Cunha, A. P. and Almeida, L. M. (1997): Antioxidant activities of some extracts of Thymus zygis. - Free Radical Research 26: 469-478. https://doi. org/10.3109/10715769709084484

Steel, R. G. and Torrie, J. H. (1986): Principles and procedures of statistics: a biometrical approach. - McGraw-Hill, New York.

Sudipta, K. M., Kumara Swamy, M., Balasubramanya, S. and Anuradha, M. (2014): Assessment of genetic fidelity, antioxidant enzyme activity and proline content of micropropagated and field grown plants of Leptadenia reticulata (Wight \& Arn.) - an endangered medicinal plant. - Plant Cell Biotechnol. Mol. Biol. 15: 127-135.

Vaskonen, T. (2003): Dietary minerals and modification of cardiovascular risk factors. $-J$. Nutr. Biochem. 14(9): 492-506. https://doi.org/10.1016/s0955-2863(03)00074-3

Wolf, B. (1982): A comprehensive system of leaf analyses and its use for diagnosing crop nutrient status. - Commun. Soil Sci. Plant Anal. 13(12): 1035-1059. https://doi. org/10.1080/00103628209367332

Yazdanparast, R. and Ardestani, A. (2007): In vitro antioxidant and free radical scavenging activity of Cyperus rotundus. - J. Medic. Food 10: 667-674. https://doi.org/10.1089/ jmf.2006.090

Zhang, W. F., Zhang, F., Raziuddin, R., Gong, H. J., Yang, Z. M., Lu, L., Ye, Q. F. and Zhou, W. J. (2008): Effects of 5-aminolevulinic acid on oilseed rape seedling growth under herbicide toxicity stress. - J. Plant Growth Regul. 27(2): 159-169. https://doi. org/10.1007/s00344-008-9042-y

Zhou, W. and Leul, M. (1999): Uniconazole-induced tolerance of rape plants to heat stress in relation to changes in hormonal levels, enzyme activities and lipid peroxidation. Plant Growth Regul. 27(2): 99-104. 